\title{
人間の把持特性に基づくロボットハンドのカ制御
}

○中沢 信明 (東北大) 池浦 良淳 (三重大) 猪岡 光 (東北大)

\section{Force control of a robot hand emulating human's grasping behavior}

Nobuaki Nakazawa(Tohoku Univ.), Ryojun Ikcura(Mic Univ.), Hikaru Inooka(Tohoku Univ.)

\section{1. 緒言}

人間は必要最小限の力で物体を把持することが知 られている。また把持物体に慣性力が生じた場合に は, 慣性力を補うように把持力を微妙に変化させて いる[1][2]. 本研究では, 把持物体の加速度の方向お よび大きさに対する人間の把持特性を調べ，それに 基づくロボットハンド制御の有効性を示す。

\section{2. 人間の把持特性}

人間の把持動作の測定装置を Fig.1に示す. 被験者 は，親指および中指で物体を把持し，ビープ音に合 わせて鉛直方向における上下振動動作 (周期: $0.4 \mathrm{sec}$ 振幅：50 mm)を行なった. Fig.2に典型的な測定波 形を示す. 図中の実線は測定値であり, 破線は次式 で与えられる理論値 (最小把持力) である。

$$
F_{1}^{*}=m(g+\alpha) / 2 \mu
$$

ここで, $m$ は物体質量, $g$ は重力加速度, $\alpha$ は加速度, 情静止摩擦係数である. 図より，人間は周期的に把 持力を変化させていることが確認できる。？その值は， 理論値とともに変化している。ここで, 次式で示さ れる Safety factor $N$ を求めた.

$$
N=F_{1} / F_{1}^{*}
$$

把持物体の加速度と Safety factor との関係を Fig.3 に示す。図中の○印は測定值である。加速度が正の 場合，すなわち物体が振幅の最下地点に到達すると きに, Safety factor は加速度によらずほほ一定值を とっている. その值は約 1.3 であり, 効率のよい把 持動作が行なわれている. 一方, 加速度が負の場合, Safety factor は大きくなり, 加速度の方向によりそ の特性が異なることが分かる。この人間の特性を加 速度の関数として, 次式で近似する.

$$
N(\alpha)= \begin{cases}\kappa & (\alpha \geq 0) \\ T \alpha^{2}+\kappa & (\alpha<0)\end{cases}
$$

ここで近似式は図中の点線で示され，パラメータの 値は, $\kappa=1.29, T=0.0427$ である.

\section{3. ロボットへの応用}

\section{1 ロボットハンドの制御}

本研究では, Fig.4に示されるロボットハンドを用 いて人間の動作に基づく把持力制御を行なう.フィ ンガ部は 2 自由度平行移動型であり, 加速度センサ を搭載し, 把持物体の加速度が観測可能である。こ

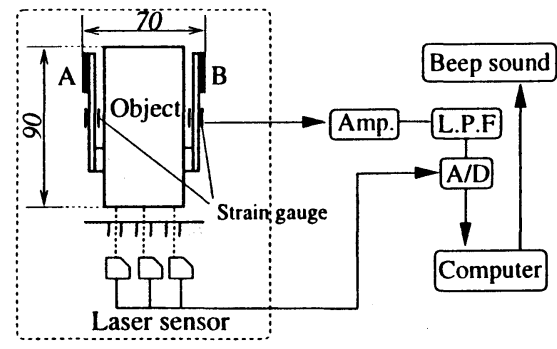

Fig.1 Experimental device to measure the grasping force

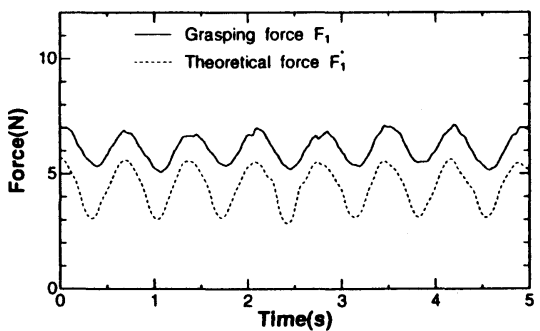

Fig.2 Time trajectories of grasping force and theoretical force

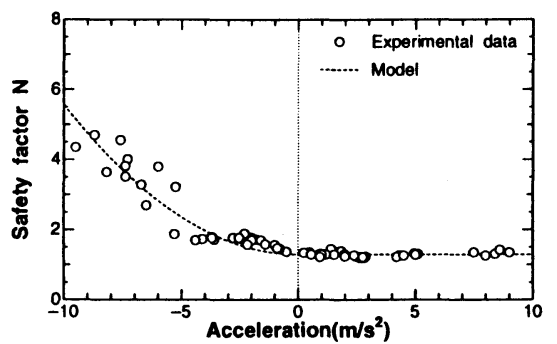

Fig.3 Relationship between acceleration and parameter $N$

こで，式（3）における Safety factor $N(\alpha)$ を用いた 場合, 目標値 $F_{i}(t)$ は次式で与えられる.

$$
F_{i}(t)=N(\alpha, t)\left\{F_{d}+F(\alpha, t)\right\}
$$

ただし， $F_{d}$ は静止状態における最小把持力, $F(\alpha, t)$ は慣性力による影響を補うために必要な最小把持力 である.ここでは, 外乱の慣性力に対してPD フィー ドバック制御による入力で把持力を制御する。.入力 $u(t)$ は次式で与えられる.

$$
u(t)=K_{p}\left\{F_{i}(t)-F(t)\right\}-K_{d} \frac{d F(t)}{d t}
$$

ここで, $K_{p}$ は比例フィードバックゲイン,$K_{d}$ は微分 フィードバックゲインである. 


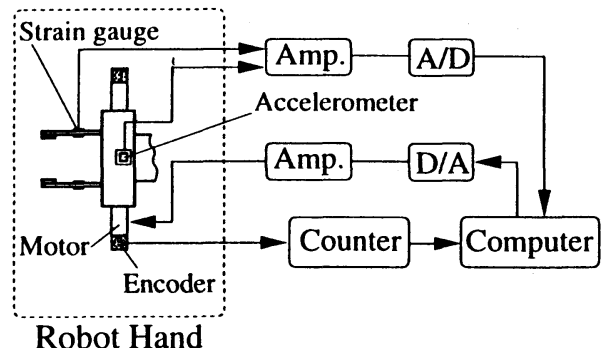

Robot Hand

Fig.4 Control system of robot hand

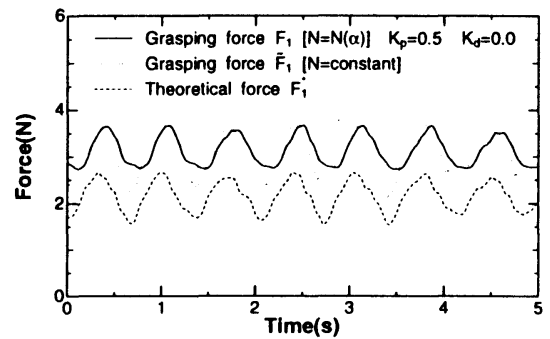

Fig.5 Experimental results of controlling the grasping force performed by the robot hand (A period of time $=0.7(\mathrm{sec})$ )

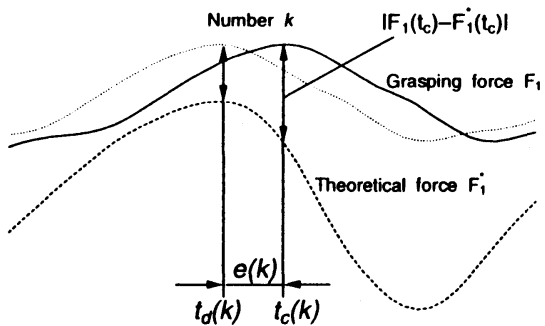

Fig.6 Typical time trajectories when the delay time occurs

\section{2 ロボットハンドによる実験結果}

前節の被験者による実験と同様に，ロボットハン ドが物体を把持した状態で，上下振動動作を行なっ た. 実験結果を Fig.5に示す。図中の実線がハンドの 把持力，破線が理論值，点線がSafety factor にした場合の把持力である.図より，ロボットハンド が慣性力を補うように把持力を制御していることが 分かる.このときの把持力の値は, 人間の場合と同 様に理論値とともに周期的に変化している. Safety factor を一定にした場合には，把持力を減少させる 時点において理論値との差が小さくなり，把持物体 を滑り落す可能性がある。一方，人間の把持動作に 基づき Safety factorを可変にした場合には，把持力 を減少させる動作が抑制され，安定な把持動作が行 なわれていることが確認できる。

\section{3 時間遅れの改善}

理論値に対して把持力が時間遅れを持つ場合, Fig.6に示されるように理論值と把持力との差 $\left|F_{1}\left(t_{c}\right)-F_{1}^{*}\left(t_{c}\right)\right|$ が大きくなり, 必要のない時点で 過大な力が加わることになる。本研究ではリアル夕 イムで各々のピーク值における時刻 $t_{c,}, t_{d}$ を検出し， $K_{d}$ を次式のように周期的に逐次更新して時間遅れを

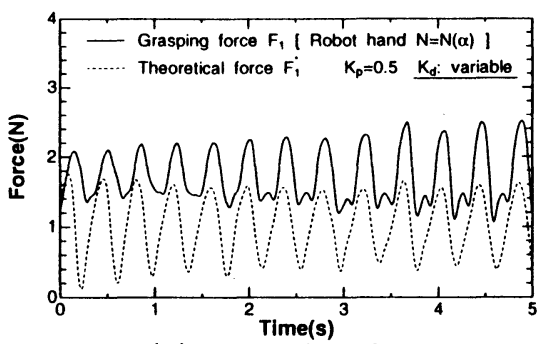

(a) Grasping force

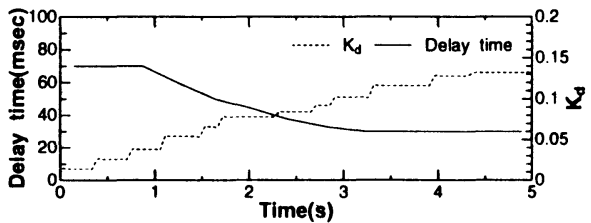

(b) Delay time and parameter $K_{d}$

Fig.7 Experimental results of controlling the grasping force under the condition that $K_{d}$ is variable:

少なくする

$$
\begin{gathered}
e(k)=t_{c}(k)-t_{d}(k) \\
K_{d}(k+1)=K_{d}(k:)+\Phi e(k)
\end{gathered}
$$

ただし，Фは収束を決定するパラメータであり，kは周 期の回数である. 振動周期を $0.4(\mathrm{sec})$ に設定したとき の測定結果を Fig.7に示す。ここでは, $K_{d}(0)=0.01$, $\Phi=0.002$ とした。図より，Koが周期的に更新され， その值は $0.12 \sim 0.13$ でほほ収束していることが分か る. 実験開始から時刻 $t=1(\mathrm{sec})$ 付近での時間遅れ は約 70(msec) であり, 把持力の時間波形と理論値 とが重なる時点において不安定な把持状態となる. 時刻 $t=1(\mathrm{sec})$ 以降は, 時間遅れが改善され, 時刻 $t=3(\mathrm{sec})$ 付近で時間遅れが収束し, 安定な把持動作 が行なわれていることが確認できる.

\section{4. 結言}

本研究では，把持物体に慣性力が生じた場合にお ける人間の把持特性をモデル化し，ロボットハンド の力制御への適用を行なった。さらに，把持力の時 間遅れを改善するための手法を提案した。 その結果, ロボットハンドが慣性力に対して効率のよい把持動 作を行なっており，人間の動作特性に基づく把持力 制御の有効性を示した。

なお, 本研究は平成 9 10 年度文部省科学研究費 (日本学術振與会特別研究員奖励費 No.6227) および 財団法人メカトロニクス技術高度化財団の補助を受 けている。.また測定にあたり，東北大学工学部機械 航空工学科 中宮賢樹氏に多大な協力を得た. 各関係 者に心から謝意を表す。

\section{参考文献}

[1] 金一煥, 仕入 英武, 猪岡 光, “人間の把持力制御特性の 実験的考察”, 人間工学,Vol.29,No.2,pp.95-102,1993.

[2] J.R.Flanagan and A.M.Wing, "The stability of precision grip forces during cyclic arm movements with a hand-held load",Exp Brain Res,105,pp.455464,1995 . 